\title{
Coping strategy and substance use disorders: The mediating role of drug hazard knowledge
}

\author{
Wahyuni Ismail, ${ }^{1 *}$ Eka Damayanti, ${ }^{1}$ Sitti Nurpahmi, ${ }^{1}$ Dayang $\mathrm{Hjh}$ Tiawa Awg Hj Hamid ${ }^{2}$ \\ ${ }^{1}$ Faculty of Tarbiyah and Teacher Training, Universitas Islam Negeri Alauddin, Makassar - Indonesia, \\ ${ }^{2}$ Faculty of Islamic Technology, Sultan Sharif Ali Islamic University, Brunei-Muara - Brunei Darussalam
}

\begin{abstract}
Substance Use Disorder (SUD) is a social phenomenon that has plagued communities, including adolescents. Coping strategy and drug hazard knowledge are seen as important factors in curbing drug use amongst young people. This study aims to identify the indirect influence of coping strategy through drug hazard knowledge as a mediator in substance use disorders. The research employed a quantitative approach with a cross-sectional design, with a sample of 381 adolescents, 313 males and 68 females, selected using a simple random sampling technique. The research instruments comprised the Drugs Abuse Screening Test-28, a coping scale, and drug hazard knowledge scale. AMOS 20.0 for Structural Equation Modelling (SEM) was used for the analysis. The results show no significant indirect influence of coping strategy through drug hazard knowledge as a mediator in substance use disorder among adolescents. This indicates that drug hazard knowledge has no significant influence on substance use disorders.
\end{abstract}

Keywords: coping strategy; drugs hazard knowledge; substance use disorders

\begin{abstract}
Abstrak: Substance Use Disorder (SUD) merupakan fenomena sosial yang melanda masyarakat, termasuk remaja. Strategi coping dan pengetahuan tentang bahaya narkoba dipandang sebagai faktor penting mencegah penyalahgunaan narkoba agar tidak menyebar terus-menerus di kalangan remaja. Penelitian ini bertujuan mengidentifikasi pengaruh tidak langsung strategi coping melalui pengetahuan tentang bahaya narkoba sebagai mediator terhadap substance use disorder. Penelitian ini merupakan kuantitatif jenis cross sectional di Pusat Rehabilitasi Narkoba di Makassar. Penelitian ini melibatkan 381 remaja yaitu 313 laki-laki dan 68 perempuan dengan teknik random sampling sederhana. Instrumen penelitian ini adalah Drug Abuse Screening Test-28, Skala Coping, dan Skala Pengetahuan tentang Bahaya Narkoba. Analisis data menggunakan AMOS 20.0 untuk Structural Equation Modelling (SEM). Hasil penelitian menunjukkan bahwa tidak ada pengaruh secara tidak langsung yang signifikan strategi coping melalui pengetahuan tentang bahaya narkoba sebagai mediator terhadap substance use disorder di kalangan remaja. Ini berarti bahwa pengetahuan tentang bahaya narkoba tidak memiliki efek mediasi yang signifikan sebagai variabel mediator.
\end{abstract}

Kata Kunci: strategi coping; pengetahuan tentang bahaya narkoba;

penyalahgunaan narkoba *Corresponding Author: Wahyuni Ismail (wahyuni.ismail@uin-alauddin.ac.id), Faculty of Tarbiyah and Teacher Training, Universitas
Islam Negeri Alauddin, Jl. Sultan Alauddin No 36, Makassar 90221-Indonesia. 


\section{Introduction}

Substances or drugs refer to the group of compounds that generally have a risk of addiction to users. According to health experts, drugs are psychotropic compounds commonly used to anesthetize patients at the time of surgery or those used to treat certain diseases. However, drugs are not intended for general consumption by the public because drug abuse can cause acute physical and psychological effects (Anggeria \& Sutriana, 2020; Pusdatin Kementerian Kesehatan RI, 2017b).

Currently, drug abuse is referred to as substance use disorder (SUD), based on the American Psychiatric Association classification of DSM-V (Diagnostic Statistical Manual of Mental Disorders) published on 18 May 2013, which replaced DSM-IV, previously published in 2000 (Jeste et al. 2013). An estimated 35 million people worldwide have a substance use disorder (UNODC, 2019). Relapse or exacerbation rates of such disorders are around $50 \%$, similar to other chronic health disorders (National Institute on Drug Abuse, 2020).

Substance use disorder is one group of chronic relapsing disorders of the brain and has significant public health and societal impact (Butelman \& Kreek, 2017). Substance use disorders are complex disorders that affect brain function and behavior and are characterized by impaired functioning and considerable harm to the individuals concerned and to society a whole (Yang et al., 2017).

Hartatik et al. (2018) show that drug abuse increased among adolescents, causing the younger generation to fall into substance use disorders and physical and mental damage in Indonesia. As cited by the National Anti-Narcotics
Agency of the Republic of Indonesia (Badan Narkotika Nasional - BNN), that the number of substance use disorders among students in 2018 (from 13 provincial capitals in Indonesia) reached 2.29 million people. One group of people prone to substance use disorders is those in the age range of 15-35 years or millennial generation (Puslitdatin BNN, 2019); as of 2020, there were 14,010 drug cases. This number increased significantly from 2018 when there were 990 cases.

Furthermore, according to the Head of BNN in South Sulawesi Province, Indonesia is already in a state of emergency about drugs, with cases increasing and the problem complicated to solve (Admin BDK Makassar, 2020). The total number of drug cases recorded in South Sulawesi Province in 2020 was 150 cases (Puslitdatin BNN, 2020).

Leni et al. (2021) state that the phenomenon of substance use disorder is still difficult to control. Even today, variations of narcotics have circulated in many countries, one example being new psychoactive substances. Despite this, public knowledge of such substances is still very low.

Adolescence represents a period of risk for initiation into substance use and the development of substance use disorder (Chaplin et al., 2018).

Another cause of substance use disorder is the personality factor, with various personality traits making individuals inclined towards substance abuse. Therefore, personality factors play an important determining role in SUD (Poonam et al., 2019). Adolescents' personality plays a role in their substance use disorder, those who become addicts have a negative self-concept and low selfesteem (Nurfantri, 2019).

One study found that delinquent behaviors were associated with worse substance use, 
showing the negative effects of delinquency on substance use (Zhang \& Slesnick, 2018). Håkansson and Jesionowska (2018) also state that binge drinking and sedatives were positively associated with violent crime, while Tomlinson (2016) explains that aggressive behavior is influenced by substance use disorder among adolescents.

Another impact of substance use disorder, as explained by Ólafsdóttir et al. (2018), is that 36\% or more of drug addicts had average, serious, or very serious depression, anxiety, and stress in Iceland. Bancin (2019) explains that the impact of substance use disorder is that it can suppress the central nerves, and lead to various cognitive, behavioral, and maladaptive problems.

Based on the results of a BNN survey in 2016, $2.2 \%$ of adolescents in Makassar were engaged in substance use disorder behavior (Pusdatin Kementerian Kesehatan RI, 2017b; Puslitdatin BNN, 2020), which raises the questions of why most related cases are the highest level and what factors cause drug abuse. These questions have motivated researchers to conduct more in-depth studies of coping strategies and drug hazard knowledge.

Moreover, it is never too late for adolescents, especially students, to be given knowledge about drug hazards and their worrying effects. They also need to be informed about the laws that prohibit drug abuse (Humas BNN, 2019).

Therefore, drug hazard knowledge is important for students and adolescents to distance themselves from SUD behavior. Students who have been given knowledge about the hazards and effects of drugs are expected to control their behavior (Pusdatin Kementerian Kesehatan RI, 2017b). Research, Data, and Information Center of the Indonesian Ministry of Health found that a lack of knowledge and socialization about the dangers of drugs among students and adolescents caused them to be easily involved in their abuse.

Adolescents are significantly at risk of engaging in deviant behavior such as SUD because with reference to the biological theory of the brain, research results show that the human brain still undergoes significant growth and development processes during adolescence (Winters \& Arria, 2012).

The Law of the Republic Indonesia No. 35 of 2009 defines drug abusers who use drugs illegally. On the other hand, the Indonesian Ministry of Health (2017); Throop \& Castellucci (2005) state that SUD uses external drugs, whose results are hazardous physically, emotionally, and mentally.

Greenglass et al. (2006) interpret coping strategies as an individual's way of dealing with and preventing physically, psychologically oppressive, or threatening situations. Such strategies aim to determine the extent of action and the consideration taken in choosing the right way to deal with the pressures on drug addicts undergoing rehabilitation (Shabrina et al., 2018).

Frydenberg and Lewis (1993) divide coping strategies into three aspects: a) Problem focus (solving the problem) as a way to focus on solving the problem such as seeking relaxing diversions, physical recreation, working hard and achieving, and focusing on the positive methods; $b$ ) referring to other examples of individuals seeking help from others about their problems such as seeking social support, seek professional help, seek spiritual support, and social action; c) nonproductive coping, namely individuals taking unproductive action in relation to life problems 
such as wishful thinking, tension reduction, keep to self, and self-blame.

Markova and Nikitskaya (2017) state that coping is an important construct in adolescents' response to the extensive stressors and adjustments they experience and explain that deviant adolescents are more likely to use disengagement coping strategies.

Modecki et al. (2021) demonstrate a clear pattern of the positive effects of moderate online coping, particularly support seeking and selfdistraction. In addition, Semaraputri et al. (2020) showed that cognitive-behavioral coping skills training influenced the coping strategies of narcotics prisoners participating in a rehabilitation program in Klinik Lapas X in Denpasar.

Bolisani and Bratianu (2018) explain that knowledge is an abstract concept without reference to the tangible world. According to Zagzebski (2017), it is a highly valued indication in which a person is in cognitive contact with reality. Shekhawat and Maheshwari (2021) conclude that educational intervention is highly effective in improving the knowledge and attitude of substance users. Policymakers should organize large-scale educational programs regarding substance abuse to curb the problem.

Kesselheim et al. (2017) explain that disseminators of emerging drug safety information should explore ways of providing user-friendly resources that can be updated in relation to new risks promptly. Likewise, Anshari et al. (2016) found a relationship between knowledge of the hazards of alcoholic beverages and the alcohol prevention stance.

Therefore, it is evident that our research needs to be conducted, as no previous study has focused on coping strategies and substance use disorder as a mediating variable in drug hazard knowledge at the same time. It is the originality of this research.

Drug hazard knowledge became a mediator variable because, at every level of education, there is no official curriculum on drug hazard knowledge, which is considered an influential component of SUD. As a mediator, automatically can be known as a direct and indirect influence.

Three hypotheses were formulated for the study: (1) there is a significant direct influence of coping strategy on substance use disorder; (2) there is a significant direct influence of drug hazard knowledge on drug abuse among adolescents; (3) there is a significant indirect influence of coping strategy through drug hazard knowledge as a mediator in substance use disorder among adolescents.

\section{Method}

\section{Research Design}

This research employs a quantitative method in the form of a survey. The survey method was cross-sectional, with data collected from respondents at a one in time (Creswell, 2013).

\section{Ethics and Participants}

The study population consisted of 579 respondents: (1) 452 (394 males and 58 female) at the Narcotics Correctional Institution Sungguminasa, and (2) 127 (104 males and 23 female) at the rehabilitation center in Baddoka Makassar. These locations were chosen because drug addicts were undergoing treatment at the centers. The study sample consisted of 381 respondents, 313 (82.15\%) males and 68 (17.85\%) females, selected using random sampling. 
Based on the results of the study, out of the total of 381 respondents, 41 (10.76\%) were teenagers in the early adolescence category, aged 13 to 15 years; 254 (66.67\%) were in, the middle category, aged 16 to 19 ; while 86 (22.57\%) aged 20 to 24 years were in the late adolescence group.

\section{Procedure}

In the first step, the researcher confirms from the Correctional Board leaders and appoints the Head of guidance Division accompanied by the Head of Administrative Sub-Division plus two other officers to spread the research instruments' scale. The study process was conducted at break time to fill in the scales. The process of sampling and completing the scale was random. If a respondent did not understand a statement, the researcher immediately provided comprehension information; this lasted for seven days.

\section{Instruments}

The research instrument was the scale designed by Frydenberg and Lewis (1993), who developed a coping strategy, namely a coping scale containing 18 items. The drug hazard knowledge scale is a scale developed by researchers is Ismail. This scale is based on indicators from Wawan (2010), comprising 23 items. The substance use disorder scale used the Drug Abuse Screening Test developed by Skinner (1982), containing 28 items. Four choices, namely, measured each scale (1) strongly disagree, (2) disagree, (3) agree (4) strongly agree.

The pilot study results from testing the scale found that the validity test of the coping strategy scale had coefficient values of 207 to .571 . In contrast, reliability had a coefficient value of .84 $\alpha$. Drug hazard knowledge showed coefficient values ranging from .313 to .772 , while reliability had a coefficient value of $.90 \alpha$. In addition, the validity of the substance use disorder scale had coefficient values of .345 to .738 , and the reliability a coefficient value of $.93 \alpha$. The scale data's complete validity and reliability analysis is presented in Table. 1.

\section{Data Analysis}

The data analysis technique used structural equation modeling (SEM). Byrne (2010) explains that this can explain the effect between variables in complex ways and the direct or indirect influence of one or more variables on other variables. The SEM data processing was performed using the AMOS 20.0 program.

\section{Results}

Before analyzing the hypotheses, the research data were analyzed descriptively to determine the minimum, maximum, mean, and standard deviation (SD) scores. According to the analysis, it was found that the respondents had high levels of coping strategy, hazard drug knowledge, and

\section{Table 1}

Results of the Validity and Reliability of the Measurement Instruments

\begin{tabular}{llc}
\hline Scale & Validity & Reliability $(\alpha)$ \\
\hline Coping & $.207-.571$ & .84 \\
Knowledge & $.313-.772$ & .90 \\
Substance & $.345-.738$ & .93 \\
\hline
\end{tabular}


substance use disorder, as the empirical mean of all the variables was more than one SD above the theoretical average. All the descriptive analysis data are presented in Table 2.

The data analysis test shows that coping strategy directly influences substance use disorder among adolescents, with a significant value of .007 ( $\mathrm{p}<.05$ ), meaning that hypothesis 1 is accepted. However, drug hazard knowledge has no direct influence on adolescents' substance use disorder, with an estimated value of 197 ( $p>.05$ ), which means that hypothesis 2 is rejected. The complete estimated value of the direct influence between the variables is presented in Table 3 .

The mediator hypothesis can identify causal effects such as independent, dependent, and mediator variables. The variable mediator can be tested using path analysis, which uses a set of multiple regression analysis to ascertain the strength of the relationship or the effect of the independent and dependent variables (Whitley \& Kite, 2013). If the calculation result is $>.08$, then there is a significant mediator effect. This method is suggested by Hair et al. (2006), who explain that the calculation of the mediator effect is made based on the value of the indirect effect.

As shown in Table 4, the statistical analysis results show no significant indirect influence of coping strategies through drug hazard knowledge as a mediator in substance use disorder, with a value of .003 , which is less than $.08(.003<.08)$. It means that the indirect variable of drug hazard knowledge has no effect as a mediator variable.

Based on the mediator test, it can be concluded that hypothesis 3 , which proposes that there is a significant indirect influence of coping strategy through drug hazard knowledge as a mediator in substance use disorder among adolescents, is rejected. The results of the mediator hypothesis test are shown in Table 4.

Table 2

Data Descriptive Analysis

\begin{tabular}{lrrrrr}
\hline Variable & N & Min & Max & Mean & SD \\
\hline Coping & 381 & 24 & 60 & 43.53 & 4.60 \\
Knowledge & 381 & 21 & 84 & 59.23 & 8.60 \\
Substance & 381 & 29 & 108 & 70.76 & 10.52 \\
\hline
\end{tabular}

Table 3

Estimated Values of Direct Variable Effects

\begin{tabular}{lrrrr}
\hline Variable & Estimate & S.E. & C.R. & p \\
\hline Coping $\rightarrow$ Knowledge & .035 & .024 & 1.437 & .076 \\
Knowledge $\rightarrow$ Substance & .097 & .113 & 0.854 & .197 \\
Coping $\rightarrow$ Substance & .048 & .020 & 2.448 & .007 \\
\hline
\end{tabular}


Table 4.

Mediating Effect Results

\begin{tabular}{llc}
\hline Path analysis & Dependent Variable & Mediator Effect \\
\hline Coping $\rightarrow$ Knowledge & Substance use disorder & .003 \\
\hline
\end{tabular}

\section{Figure 1}

Indirect Influence of Coping Strategy through Drug Hazard Knowledge as a Mediator in Substance Use Disorder

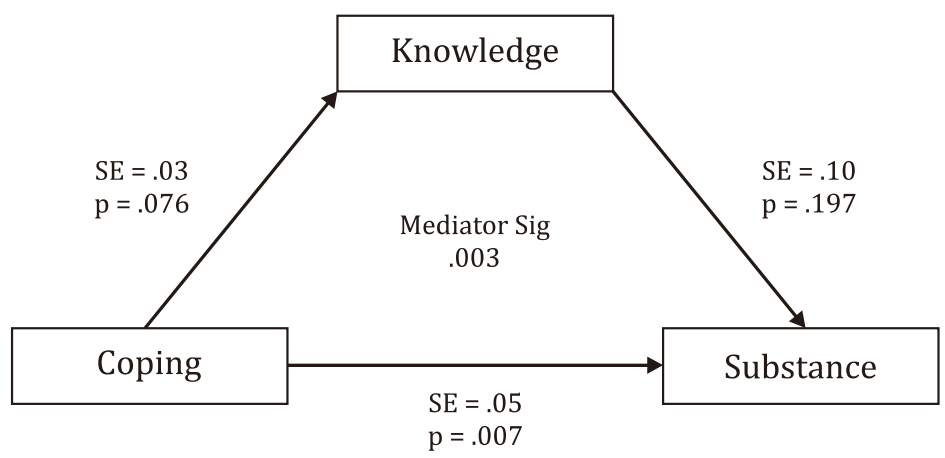

\section{Discussion}

The study results based on the SEM analysis show that there is no significant indirect effect of coping strategies on substance use disorder through drug hazard knowledge as a mediator among adolescents.

The results are unexpected, as it was understood that individuals could distinguish between good behavior and not good behavior while the knowledge.

Haqi and Alayyannur (2020) explain that knowledge is one of the important factors in preventing diseases and work accidents, while Bolisani and Bratianu (2018) argue that knowledge is justified true belief is shown to have the limitations given by the justification condition.
According to the results of this study, the number of adolescents involved in substance use disorder is also reinforced by the respondents' statements, who expressed their hope of joining rehabilitation. In contrast, only six adolescents $(1.57 \%)$ said there should be socialization about drug hazard knowledge.

Regarding the ability of this cognitive level, the respondents said that their stimulus was smoking. Smoking is a style or culture among adolescents. The study results showed that in general, adolescents had smoked and that smoking was the main gateway to drug abuse in Medan (Dalimunte \& Harahap 2019).

The same study reinforced by Azmiyardi (2020) also found there was an effect of smoking 
behavior and alcohol consumption on the risk of narcotics use among high school students in Singkawang.

A study from Bline et al. (2020) shows that tobacco smoke exposure has inheritable effects on germ cells, with negative health implications for the resulting offspring. Given the historical prevalence of tobacco smoking, it is also a substance with a legacy of exposure that is carried among us today and will continue to be passed along to the next generations.

Hardy et al. (2021) conducted different this research, with their results showing that low knowledge of adolescents of drug information affected unfavorable attitudes of $54.6 \%$. On the other hand, the resulting good attitude was 58.6\% with high knowledge of drugs. Therefore, adolescents' high knowledge of drugs will result in a good attitude; i.e., they will avoid drug abuse.

Moreover, the study by Damsere-Derry et al. (2017) showed that provision of authoritative information advising motorists about safe, responsible, or low-risk levels of alcohol consumption was imperative. Many traffic violations including drink driving were reported.

This results study also contradicts the results of Asman et al. (2021), who found a significant relationship between knowledge about drugs and drug use, and there was also a significant relationship between attitudes towards drugs and drug use.

In addition, study Aditya and Mina (2019), the implementation of community service programs in the socialization of the dangers of drugs and alcoholic beverages had a positive impact on the performance of such programs. This activity can be carried out properly.
Alves et al. (2021) show the importance of providing accurate information about the health risks related to each type of drug; the addiction of the influence of peers on the consumption of psychoactive substances; and the importance of creating a space for healthy sharing and coexistence among students without relying on drug use.

Other research results that are also contradictory to those of this study include those of Prisaria (2012), who found a positive relationship between student knowledge about drugs and preventive measures. The higher their knowledge, the higher the level of drug prevention.

But in reality, based on these research results, drug hazard knowledge is not effective in preventing substance use disorder among adolescents. In this study, it was found that many factors influence adolescents' abuse of drugs, but the main factor is peer influence (46.98\%), the second factor are smoking and alcohol consumption.

This study is in accordance with that of Zapolski et al. (2019), who found that among the factors affecting SUD are peer group and other social influences. National Institute on Drug Abuse (2020) recorded that people generally take substances for several reasons: to feel good, to feel better, and to do better and that peer pressure can be very strong.

Olalekan (2019) explains that many risk factors can contribute to an adolescent experimenting with a substance, such as lack of family cohesion, a poor parent-adolescent relationship, and substance using friends, which, all of all risk factors associated with adolescent substance use. 
Therefore, the findings of this study can be utilized to teach teenagers to avoid peers who have taken drugs. The research conducted by Rahmadika (2018) found that one of the factors leading to drug abuse is using drugs as an escape when someone has a problem. Prajayanti and Maslikhah (2020) revealed that students' knowledge of the dangers of drug use was only $30 \%$ before the delivery of material about the dangers of using narcotics, psychotropic substances, and addictive drugs, when it increased to $90 \%$.

Coping strategies significantly influence the development and course of both SUD and major depressive disorder (Adan et al. 2017). This results study is consistent with the results of Ismail et al. (2014) found that the higher the level of coping strategies, the lower adolescents' SUD-related behavior. The results obtained by Akcan et al. (2021) from the participation of 735 (209 male and 526 female) university students also show that coping strategies have a relationship with alcohol use disorder.

In the problem-solving process, individuals sometimes engage in positive coping strategies and sometimes negative ones, such as taking drugs, to reduce anxiety. Apart from drugs and alcohol, cigarettes are also commonly used to reduce anxiety. According to Wagner and Atkins (2000) and Myers et al. (2009), the content of drugs, alcohol, and nicotine is believed to reduce anxiety immediately.

Mahmood (2001) states that although many people know about the dangers of drugs and alcohol, for example pregnant women, they continue to use them. Such people always face high pressure and do not act healthily to solve problems because they continue to use drugs, not knowing how to solve their problems.
The study results obtained by Hastuti and Megawati (2019) indicate that adolescents as potential human resources, as successors of this nation, can not function optimally because of the presence of some who commit drug abuse. Therefore, activities that educate about the dangers of using illegal drugs can prevent adolescents from consuming them.

Wills et al. (1996) reveal that in general there are two types of coping strategy: engagement strategy, related to how to find solutions; and disengagement strategy, which directs individuals to find peace from negative effects. Furthermore, they also explain that coping strategies are related to drug addiction behavior, especially the disengagement coping strategies associated with drug abuse among adolescents.

Schwinn et al. (2016) also found that the reasons for drug use among adolescents can be to cope with mood changes, low self-esteem, or discomfort in social settings.

Therefore, it is very necessary to improved this coping strategy to reduce drug abuse behavior in adolescents. Ismail et al. (2014) found that coping strategies such as focusing on solving the problem and referring to others (seeking social or spiritual support) affected minimizing drug abuse behavior. It means that the higher the level of coping strategy, the lower the level of drug abuse amongst adolescents in Makassar.

Shabrina Mardiah and Utami (2018) study about coping strategy on Muslim women undergoing drug rehabilitation at Palembang shows that since their time at the rehabilitation center, almost respondents inclined to use type as coping strategy is emotion focussed coping, and only one respondent using solving the problem. 
Chuang et al. (2017) show that the combination of trait impulsivity and a history of behavioral addictions increases the risk of current and future drug use in adolescents, to a greater extent than risk factors alone. Substance use is particularly problematic among adolescents, with recent Australian research indicating that among those aged 12-17 years old, approximately threequarters had tried alcohol, one in 10 had put themselves at risk of alcohol-related harm on a monthly basis, and one in six has tried an illicit drug (Newton et al., 2017).

Meanwhile, according to Folkman and Lazarus (1984) the purpose of coping is to reduce painful environmental conditions, adapt to negative events and realities, maintain emotional balance, maintain a positive self-image, and maintain satisfying relationships with others.

The study results of Rahman (2018) found that many types of coping do everyone, such as social support, problem-focused coping, positive thinking, skill solving the problem and emotion, focused coping to reduce the stress condition of prisoners user drugs Institution Corrections Woman Class IIA at Malang.

Sulaiman et al. (2021) study results show that adolescents need a social supporting environment, such as strong family relationships, positive peer influence, and good role models. All those components can provide them with protective factors to prevent them from becoming involved in risky behavior such as substance use disorder.

Taylor (2003) and Weiten (2011) explain that when someone is experiencing problems or stress, the brain sends signals along two lines. The pathway through the nervous system automatically controls the release of the catecholamine hormone, which helps mobilize the body to action.
The path through the pituitary gland and endocrine system controls the release of corticosteroid hormones, increases energy, and counteracts tissue inflammation, which is called stress-fighting constructive powers. No coping strategy can guarantee success. Even the best response may turn out to be ineffective in some circumstances. Therefore, adolescents need to strengthen coping strategies, not take shortcuts to overcome problems through substance use disorder.

$\mathrm{Wu}$ et al. (2016) emphasize that repeated drug use may compromise self-control as a coping resource, which in turn may generate stress, and in the absence of more effective self-regulation strategies result in risky sexual behaviours in response to stress.

The result of this study shows that there is no effect of coping strategies on substance use disorder through drug hazard knowledge as a mediator. It means that hazard drug knowledge is not fully integrated with individuals' behavior. Adolescents should integrate drug hazard knowledge with positive behavior, which will prevent them from drug addiction behavior.

The number of adolescents involved in substance use disorder in this study may be caused by the respondents' inability to think well and not having drug information. Hartatik et al. (2018) report that having the minimum drug hazard knowledge is one of the most potential problems, causing the younger generation to fall into SUD.

Hardy et al. (2021) that biggest influence related to drug abuse is the means of obtaining fast information through electronic media, supported by the global influence, where there is no longer any physical distance. All information that 
teenagers want can be obtained within a short time and is within their grasp.

It is reinforced by Squeglia and Cservenka (2017) research, who explain that adolescence is a time of vulnerability and a very risky time of experiencing SUD. It is illustrated by the latest neuropsychological and neuroimaging studies, which have elucidated the underlying neural vulnerabilities that contribute to predictive of substance use since adolescents.

Becker et al. (2017) also found that the environment and positive or negative experiences can also influence the brain and affect vulnerability to drug addiction among males and females. Smith et al. (2020) also argued that adolescents at SUD risk had hindered neurological development, which can cause problems with memory and self-regulation, and in turn disrupt their education, relationships, and life opportunities. National Institute on Drug Abuse (2020) explains that for teens, using substances when the brain is still developing may cause lasting brain changes and put the users at increased risk of dependence.

The findings of this result study contradict that of previous research such as the Indonesian Ministry of Health (Pusdatin Kementerian Kesehatan RI, 2017a) and Khairunnisa \& Akbar (2020). They report that knowledge about drugs can help individuals avoid drug abuse behavior.

\section{Conclusion}

This study has shown that there are no significant effects of coping strategies on substance use disorder through drug hazard knowledge as a mediator. This means that drug hazard knowledge as variable mediator is ineffective in decreasing or avoiding substance use disorder behavior among adolescents in Makassar.

The nonsignificant findings may be due to certain limitations of the study, such as the respondents' limited ability to think because they had used drugs, the instability of their psychological condition, or that the time was not right when the respondents filled in the scale.

Nevertheless, drug hazard knowledge is still important to be applied immediately, especially in all educational institutions. This study also indicates that the cause of adolescents in Makassar suffering from substance use disorder is the influence of peers who have used drugs, smoking habits, and alcohol consumption habits. Therefore, it is recommended for adolescents to avoid or prevent substance abuse disorder by saying no to cigarettes, drinking alcohol, and taking drugs.

The first step could be to increase the campaign to optimize coping strategies. If adolescents have a high coping strategy, this can control their substance use disorder behavior. Although drug hazard knowledge does not significantly influence substance use disorder, the Government still has the responsibility to design and implement programs to disseminate such knowledge at every level of education.[]

\section{References}

Adan, A., Antúnez, J. M., \& Navarro, J. F. (2017). Coping strategies related to treatment in substance use disorder patients with and without comorbid depression. Psychiatry Research, 251, 325-332. https://doi.org/10.1016/j.psychres.2017.02.035 
Aditya, R., \& Mina, R. (2019). Sosialisasi penguatan pemahaman masyarakat terhadap bahaya narkoba dan minuman beralkohol. Monsu'ani Tano: Jurnal Pengabdian Masyarakat, 2(2), 90-96. https://doi.org/10.32529/tano.v2i2.382

Admin BDK Makassar. (2020, February 19). Kepala BNN: Indonesia sudah pada level darurat narkoba. Bppk.Kemenkeu.Go.Id. https://bppk.kemenkeu.go.id/content/berita/balai-diklat-keuanganmakassar-kepala-bnn-indonesia-sudah-pada-level-darurat-narkoba-2020-02-19-0de63557/

Akcan, G., Öztürk, E., \& Erdoğan, B. (2021). Corrigendum to "The investigation of the mediating role of coping strategies on the relationship between childhood traumas, depression and alcohol use disorder in university students" [Journal of Substance Abuse Treatment 123 (2021) 108305]. Journal of Substance Abuse Treatment, 126, 108332. https://doi.org/10.1016/j.jsat.2021.108332

Alves, R., Precioso, J., \& Becoña, E. (2021). llicit drug use among college students: The importance of knowledge about drugs, live at home and peer influence. Journal of Psychoactive Drugs, 53(4), 329-338. https://doi.org/10.1080/02791072.2020.1865592

Anggeria, E., \& Sutriana, S. (2020). Penyuluhan bahaya narkoba di SMA Bayangkara. Mitra Keperawatan Dan Kebidanan Prima, 2(1).

Anshari, F., Eka, N. L. P., \& Lasri, L. (2016). Hubungan pengetahuan tentang bahaya minuman beralkohol dengan sikap pencegahan alkoholik pada mahasiswa Program Studi Agribisnis Universitas Tribhuwana Tunggadewi (Unitri) Malang. Nursing News: Jurnal Ilmiah Keperawatan, 1(2). https://doi.org/10.33366/nn.v1i2.430

Asman, A., Liza, L., \& Sinthania, D. (2021). The relationship of adolescent knowledge level and attitude about drugs with the event of drugs using in Korong Parak Jua Nagari Lurah Ampalu SubDistrict VII Koto Sungai Sarik, Padang Pariaman Regency. Journal Scientific of Mandalika (JSM), 2(8), 351-359.

Azmiardi, A. (2020). Pengaruh perilaku merokok, konsumsi alkohol dan hiburan malam terhadap risiko penggunaan narkotika. Faletehan Health Journal, 7(1), 30-36. https://doi.org/10.33746/fhj.v7i1.86

Bancin, L. J. (2019). Gambaran umur dan pekerjaan dengan lama pemakian zat pada orang dengan gangguan penyalahgunaan zat. Jurnal Ilmiah Kebidanan Imelda, 5(2), 78-81. https://doi.org/10.52943/jikebi.v5i2.173

Becker, J. B., McClellan, M. L., \& Reed, B. G. (2017). Sex differences, gender and addiction. Journal of Neuroscience Research, 95(1-2), 136-147. https://doi.org/10.1002/jnr.23963

Bline, A. P., Dearfield, K. L., DeMarini, D. M., Marchetti, F., Yauk, C. L., \& Escher, J. (2020). Heritable hazards of smoking: Applying the "clean sheet" framework to further science and policy. Environmental and Molecular Mutagenesis, 61(9), 910-921. https://doi.org/10.1002/em.22412

Bolisani, E., \& Bratianu, C. (2018). The Elusive Definition of Knowledge. In Knowledge Management and Organizational Learning (Vol. 4, pp. 1-22). Springer. https://doi.org/10.1007/978-3-319-60657-6_1

Butelman, E. R., \& Kreek, M. J. (2017). Medications for substance use disorders (SUD): Emerging approaches. Expert Opinion on Emerging Drugs, 22(4), 301-315. https://doi.org/10.1080/14728214.2017.1395855

Byrne, B. M. (2010). Structural equation modeling with AMOS: Basic concepts, applications, and programming. New York: Routledge, Taylor \& Francis Group. 
Chaplin, T. M., Niehaus, C., \& Gonçalves, S. F. (2018). Stress reactivity and the developmental psychopathology of adolescent substance use. Neurobiology of Stress, 9, 133-139. https://doi.org/10.1016/j.ynstr.2018.09.002

Chuang, C.-W. I., Sussman, S., Stone, M. D., Pang, R. D., Chou, C.-P., Leventhal, A. M., \& Kirkpatrick, M. G. (2017). Impulsivity and history of behavioral addictions are associated with drug use in adolescents. Addictive Behaviors, 74, 41-47. https://doi.org/10.1016/j.addbeh.2017.05.021

Creswell, J. W. (2013). Research design qualitative, quantitative, and mixed methods approaches. California: SAGE Publications, Inc.

Dalimunte, N., \& Dewi Harahap, R. S. (2019). Pengaruh perilaku merokok terhadap penyalahgunaan NAPZA di UPMI. Jurnal Riset Hesti Medan Akper Kesdam I/BB Medan, 4(1), 1. https://doi.org/10.34008/jurhesti.v4i1.51

Damsere-Derry, J., Palk, G., \& King, M. (2017). Motorists' knowledge, attitudes and practices toward alcohol-impaired driving/riding in Ghana. Traffic Injury Prevention, 18(1), 28-34. https://doi.org/10.1080/15389588.2016.1193172

Folkman, S., \& Lazarus, R. (1984). Stres appraisial \& coping strategy. McGraw-Hill.

Frydenberg, E., \& Lewis, R. (1993). Adolescent coping scale. Administrator's scala. The Australian Council for Educational Research Ltd.

Greenglass, E., Fiksenbaum, L., \& Eaton, J. (2006). The relationship between coping, social support, functional disability and depression in the elderly. Anxiety, Stress \& Coping, 19(1), 15-31. https://doi.org/10.1080/14659890500436430

Hair, J. F., Babin, B. J., Tatham, R. L., Anderson, R. E., \& Black, W. C. (2006). Multivariate data analysis (6th ed.). Pearson Prentice Hall.

Håkansson, A., \& Jesionowska, V. (2018). Associations between substance use and type of crime in prisoners with substance use problems \&ndash; a focus on violence and fatal violence. Substance Abuse and Rehabilitation, 9, 1-9. https://doi.org/10.2147/SAR.S143251

Haqi, D. N., \& Alayyannur, P. A. (2020). Analysis of worker's level of knowledge on handling chemicals in oil and gas industry laboratory of PT "X" Indonesia. Indian Journal of Forensic Medicine \& Toxicology, 14(2), 1218-1223. https://doi.org/10.37506/ijfmt.v14i2.3072

Hardy, S., Tukayo, I. J. H., \& Saljan, M. (2021). The influence of youth' understanding of drugs towards its abuse in the Indonesia-Papua New Guinea border. Journal of Islamic Nursing, 6(1), 1-7. https://doi.org/10.24252/join.V6I1.21086

Hartatik, Febriyanto, F., \& Munawaroh, H. (2018). Development of applications about hazards and preventions of drug based on Android. IOP Conference Series: Materials Science and Engineering, 333(1), 012104. https://doi.org/10.1088/1757-899X/333/1/012104

Hastuti, E. D., \& Megawati, A. (2019). Edukasi resiko penyalahgunaan obat pada remaja usia produktif di Kudus. Jurnal Pengabdian Kesehatan, 2(1). https://doi.org/10.31596/jpk.v2i1.23

Humas BNN. (2019, September 11). Penyebab dan dampak penyalahgunaan narkoba di kalangan remaja. Badan Narkotika Nasional Kabupaten Lampung Selatan.

Ismail., W., Kamal, M., Nasrudin, N., \& Fauziah, F. (2014). Pengaruh coping strategy terhadap penyalahgunaan dadah dalam kalangan pelajar. Education Transformation Towards a Developed Nation, 3047-3069.

Ismail, W. (2017). Teori Biologi tentang perilaku penyalahgunaan narkoba. Jurnal Biotek, 5(1), 127-143. https://doi.org/10.24252/jb.v5i1.3453 
Jeste, D. L., Liebermen, J. A., Fassler, T. D., \& Peele, S. R. (2013). Diagnostic and statistical manual of mental disorder (5th ed.). American Psychiatrict Publishing.

Kesselheim, A. S., McGraw, S. A., Dejene, S. Z., Rausch, P., Dal Pan, G. J., Lappin, B. M., Zhou, E. H., Avorn, J., \& Campbell, E. G. (2017). Patient and physician perceptions of drug safety information for sleep aids: A qualitative study. Drug Safety, 40(6), 531-542. https://doi.org/10.1007/s40264-017-0516-3

Khairunnisa, Z., \& Akbar, T. I. S. (2020). Description of knowledge levels about drug abuse in the Medical Students 2019 Universitas Malikussaleh. Averrous: Jurnal Kedokteran dan Kesehatan Malikussaleh, 6(2), 23-28. https://doi.org/10.29103/averrous.v6i2.2225

Leni, N. M., Aryani, L. N. A., \& Westa, I. W. (2021). Mengenal New Psychoactive Substances (NPS): Sebuah tinjauan pustaka. Intisari Sains Medis, 12(1), 275-284. https://doi.org/10.15562/ism.v12i1.929

Mahmood, N. M. (2001). Perubahan strategi daya tindak dalam pusat pemulihan: Penelitian enam bulan. Jurnal Psikologi Malaysia, 15, 89-118.

Markova, S., \& Nikitskaya, E. (2017). Coping strategies of adolescents with deviant behaviour. International Journal of Adolescence and Youth, 22(1), 36-46. https://doi.org/10.1080/02673843.2013.868363

Modecki, K. L., Duvenage, M., Uink, B., Barber, B. L., \& Donovan, C. L. (2021). Adolescents' online coping: When less is more but none is worse. Clinical Psychological Science, 216770262110289. https://doi.org/10.1177/21677026211028983

Myers, R., Chou, C.-P., Sussman, S., Baezconde-Garbanati, L., Pachon, H., \& Valente, T. W. (2009). Acculturation and substance use: Social influence as a mediator among hispanic alternative high school youth. Journal of Health and Social Behavior, 50(2), 164-179. https://doi.org/10.1177/002214650905000204

National Institute on Drug Abuse. (2020, June). Drugs, brains and behavior: The science of addiction (N. D. Volkow (ed.)). National Institutes of Health. https://www.drugabuse.gov/sites/default/files/ soa.pdf

Newton, N. C., Champion, K. E., Slade, T., Chapman, C., Stapinski, L., Koning, I., Tonks, Z., \& Teesson, M. (2017). A systematic review of combined student- and parent-based programs to prevent alcohol and other drug use among adolescents. Drug and Alcohol Review, 36(3), 337-351. https://doi.org/10.1111/dar.12497

Nurfantri, N. (2019). Identifikasi faktor-faktor yang menyebabkan penyalahgunaan zat adiktif pada anak jalanan di Kota Kendari. Preventif Journal, 2(2), 70-74. https://doi.org/10.37887/epj.v2i2.5433

Ólafsdóttir, J., Hrafnsdóttir, S., \& Orjasniemi, T. (2018). Depression, anxiety, and stress from substance use disorder among family members in Iceland. Nordic Studies on Alcohol and Drugs, 35(3), 165-178. https://doi.org/10.1177/1455072518766129

Olalekan, R. M. (2019). Public Health Impact of Substance Use on Adolescent: A Snapshot of Yenagoa in Bayelsa State, Nigeria. American Journal of Biomedical Science \& Research, 4(3), 183-196. https://doi.org/10.34297/AJBSR.2019.04.000796

Poonam, B., Karun, B., Angad, S. H., Hemank, W., Dhruvendra, L., \& Shradha, P. (2019). Assessment of personality factors among patients presenting with different substance use disorders. Journal of Evolution of Medical and Dental Sciences, 8(20), 1656-1661. https://doi.org/10.14260/jemds/2019/366 
Prajayanti, H., \& Maslikhah, M. (2020). Penyuluhan tentang Bahaya Penggunaan Narkotika, Psikotropika dan Obat-obat Adiktif di MAS Yapensa Jenggot Kota Pekalongan. Jurnal ABDIMAS-HIP: Pengabdian kepada Masyarakat, 1(1), 30-34. https://doi.org/10.37402/abdimaship.vol1.iss1.82

Prisaria, N. (2012). Hubungan pengetahuan dan lingkungan sosial terhadap tindakan pencegahan penyalahgunaan NAPZA pada siswa SMAN 1 Jepara. Universitas Diponegoro.

Pusdatin Kementerian Kesehatan RI. (2017a). Sistem informasi narkoba Kementerian Kesehatan.

Pusdatin Kementerian Kesehatan RI. (2017b). Anti narkoba sedunia 26 Juni' 17. InfoDATIN: Pusat Data dan Informasi Kementerian Kesehatan RI, 1-7.

Puslitdatin BNN. (2019, August). Penggunaan narkotika di kalangan remaja meningkat. Badan Narkotika Nasional Republik Indonesia. https://bnn.go.id/penggunaan-narkotika-kalanganremaja-meningkat/

Puslitdatin BNN. (2020). Data statistik penanganan kasus narkoba. Badan Narkotika Nasional Republik Indonesia. https://puslitdatin.bnn.go.id/portfolio/data-statistik-kasus-narkoba/

Rahmadika, K. (2018). Penyalahgunaan narkoba pada warga binaan di Rutan Klas IA Surakarta. Universitas Muhammadiyah Surakarta.

Sanderson. (2003). Health psychology. John Wiley \& Sons, Limited.

Schwinn, T. M., Schinke, S. P., Hopkins, J., \& Thom, B. (2016). Risk and protective factors associated with adolescent girls' substance use: Data from a nationwide Facebook sample. Substance Abuse, 37(4), 564-570. https://doi.org/10.1080/08897077.2016.1154495

Semaraputri, S. A. K. T., Hamidah, H., \& Budisetyani, I. G. A. P. W. (2020). Cognitive-behavioral coping skill training pada narapidana yang sedang menjalani program rehabilitasi. Jurnal Diversita, 6(2), 183-193. https://doi.org/10.31289/diversita.v6i2.4102

Shabrina, T., Mardiah, A., \& Utami, F. T. (2018). Strategi coping klien muslimah yang menjalani rehabilitasi narkoba. Psikis: Jurnal Psikologi Islami, 4(2), 124-132. https://doi.org/10.19109/psikis.v4i2.2451

Shekhawat, V. S., S.R., G. S., \& Maheshwari, S. K. (2021). Impact of educational intervention on knowledge and attitude related to substance abuse among inmates of de-addiction centers of selected districts, Rajasthan. International Journal of Nursing Science Practice and Research, 7(1), 55-61.

Skinner, H. A. (1982). The drug abuse screening test. Addictive Behaviors, 7(4), 363-371. https://doi.org/https://doi.org/10.1016/0306-4603(82)90005-3

Smith, N. S., Vasques, P. J., Emelogu, N. A., Hayes, A. E., Engebretson, J., \& Nash, A. J. (2020). The good, the bad, and recovery: Adolescents describe the advantages and disadvantages of alternative peer groups. Substance Abuse: Research and Treatment, 14(117822182090935). https://doi.org/10.117/1178221820909354

Squeglia, L. M., \& Cservenka, A. (2017). Adolescence and drug use vulnerability: Findings from neuroimaging. Current Opinion in Behavioral Sciences, 13, 164-170. https://doi.org/10.1016/ j.cobeha.2016.12.005

Sulaiman, W. S. W., Kamaluddin, M. R., Zakaria, E., Ibrahim, F., Hassan, N., Manap, J., Nen, S., Zamani, Z. A., \& Yusooff, F. (2021). Exploring gender differences in the vulnerability towards drug abuse among adolescents in Malaysia. Psikohumaniora: Jurnal Penelitian Psikologi, 6(1), 1-12. https://doi.org/10.21580/pjpp.v6i1.6679

Throop, R. . K., \& Castellucci, M. B. (2005). Reaching your potential: personal and professional development. Thomson Delmar Learning. 
Tomlinson, M. F., Brown, M., \& Hoaken, P. N. S. (2016). Recreational drug use and human aggressive behavior: A comprehensive review since 2003. Aggression and Violent Behavior, 27, 9-29. https://doi.org/10.1016/j.avb.2016.02.004

UNODC. (2019). World Drug Report 2019: 35 million people worldwide suffer from drug use disorders while only 1 in 7 people receive treatment. United Nations Office on Drugs and Crime. https://www.unodc.org/unodc/en/frontpage/2019/June/world-drug-report-2019_-35million-people-worldwide-suffer-from-drug-use-disorders-while-only-1-in-7-people-receivetreatment.html

Wagner, E. F., \& Atkins, J. H. (2000). Smoking among teenage girls. Journal of Child \& Adolescent Substance Abuse, 9(4), 93-110. https://doi.org/10.1300/J029v09n04_06

Wawan, A., \& M., D. (2010). Teori dan pengukuran pengetahuan sikap dan perilaku manusia. Nuha Medika.

Weiten, W. (2011). Psychology: Theme and variations. Wadsworth Cengage Learning.

Whitley, B. E., \& Kite, M. E. (2013). Principles of research in behavioral science (H. L. Adams (ed.)). Psychology Press.

Wills, T. A., McNamara, G., Vaccaro, D., \& Hirky, A. E. (1996). Escalated substance use: A longitudinal grouping analysis from early to middle adolescence. Journal of Abnormal Psychology, 105(2), 166-180. https://doi.org/10.1037/0021-843X.105.2.166

Winters, K. C., \& Arria, A. (2012). Adolescent brain development and drugs. National Institute of Health Public Access, 18(2), 21-24.

Wu, Z. H., Tennen, H., Hosain, G. M. M., Coman, E., Cullum, J., \& Berenson, A. B. (2016). Stress mediates the relationship between past drug addiction and current risky sexual behaviour among lowincome women. Stress and Health, 32(2), 138-144. https://doi.org/10.1002/smi.2587

Yang, L. H., Wong, L. Y., Grivel, M. M., \& Hasin, D. S. (2017). Stigma and substance use disorders: An international phenomenon. Current Opinion in Psychiatry, 30(5), 378-388. https://doi.org/10.1097/YC0.0000000000000351

Zagzebski, L. (2017). What is knowledge? In J. Greco \& E. Sosa (Eds.), The Blackwell guide to epistemology (pp. 92-116). Blackwell Publishing Ltd. https://doi.org/10.1002/9781405164863.ch3

Zapolski, T. C. B., Clifton, R. L., Banks, D. E., Hershberger, A., \& Aalsma, M. (2019). Family and peer influences on substance attitudes and use among juvenile justice-involved youth. Journal of Child and Family Studies, 28(2), 447-456. https://doi.org/10.1007/s10826-018-1268-0

Zhang, J., \& Slesnick, N. (2018). Substance use and social stability of homeless youth: A comparison of three interventions. Psychology of Addictive Behaviors, 32(8), 873-884. https://doi.org/10.1037/adb0000424 